\section{Paraquat Kills Geyer Larkspur ${ }^{1}$}

\section{N. HYDER}

Range Scientist, Plant Science Research Division, Agricultural Research Service, U.S. Department of Agriculture, Fort Collins, Colorado.

\section{Highlight}

Geyer larkspur, a poisonous, perennial forb, is highly susceptible to paraquat applied when flowering stems are slightly above ground. At 1/2 1b./acre, paraquat killed 90 to $95 \%$ of geyer larkspur, but was less effective when the treatment was preceded with 2,4-D at $2 \mathrm{lb}$./acre. Textile onion and most annual species were susceptible to paraquat, while all other perennial species were resistant. There was some reduction in herbage yields in the year of treatment. Although paraquat is not registered for controlling geyer larkspur, it could be considered for that purpose.

Geyer larkspur (Delphinium geyeri Greene) is a poisonous perennial plant of open plains and mountain slopes below 8,000 feet elevation in Colorado, Wyoming and Utah (Fig. 1). Although ranchers can avoid death losses by keeping cattle away from areas infested with geyer larkspur from

${ }^{1}$ Cooperative investigations of the Plant Science Research Division, Agricultural Research Service, U.S. Department of Agriculture, and Colorado Agricultural Experiment Station, Fort Collins. Supported in part by the Chevron Chemical Company. Scientific Series Paper No. 1690, Colorado Agricultural Experiment Station. Received for publication October 14, 1971. about mid-April through July, many of them either lack alternate sources of forage or must constantly defer grazing of larkspur pastures, which forces overgrazing and declining productivity on other range areas. Either way the economic losses are serious. Unfortunately, ranchers cannot solve these problems satisfactorily without an effective and profitable way of either controlling the plants or suppressing the poison in the animals.

Geyer larkspur plants generally recover from an application of (2,4-dichlorophenoxy)acetic acid $(2,4-D)$ by initiating shoot and root growth, the year after spraying, from previously dormant buds on vertical rootstocks (Hyder, 1971; Hyder and Sabatka, 1972). Therefore, it may be possible to increase plant mortality by breaking dormancy of rootstock buds and thus improve the movement of 2,4-D. Since defoliation often promotes activity in dormant buds, 1,1'-dimethyl-4,4'bipyridium ion (paraquat) might be used to increase the effect of 2,4-D. Paraquat is essentially a non-selective contact herbicide that desiccates and defoliates all plants. After entering tissues of green plants, paraquat is metabolically broken down and this process generates hydrogen peroxide, which destroys plant cells (Calderbank, 1968). Upon contact with soil, paraquat is quickly inactivated by adsorption to clay particles (Calderbank, 1968).

On rangeland, paraquat usually kills annual plants; whereas, most perennials grow back after treatment (Evans et al., 1967; Kay, 1964, 1968, 1970; Sneva, 1967; Wallace et al., 1966).

This paper reports the effects of spraying geyer larkspur and many other plant species with 2,4-D and paraquat at various rates and times. Mechanical defoliation treatments were included to determine 

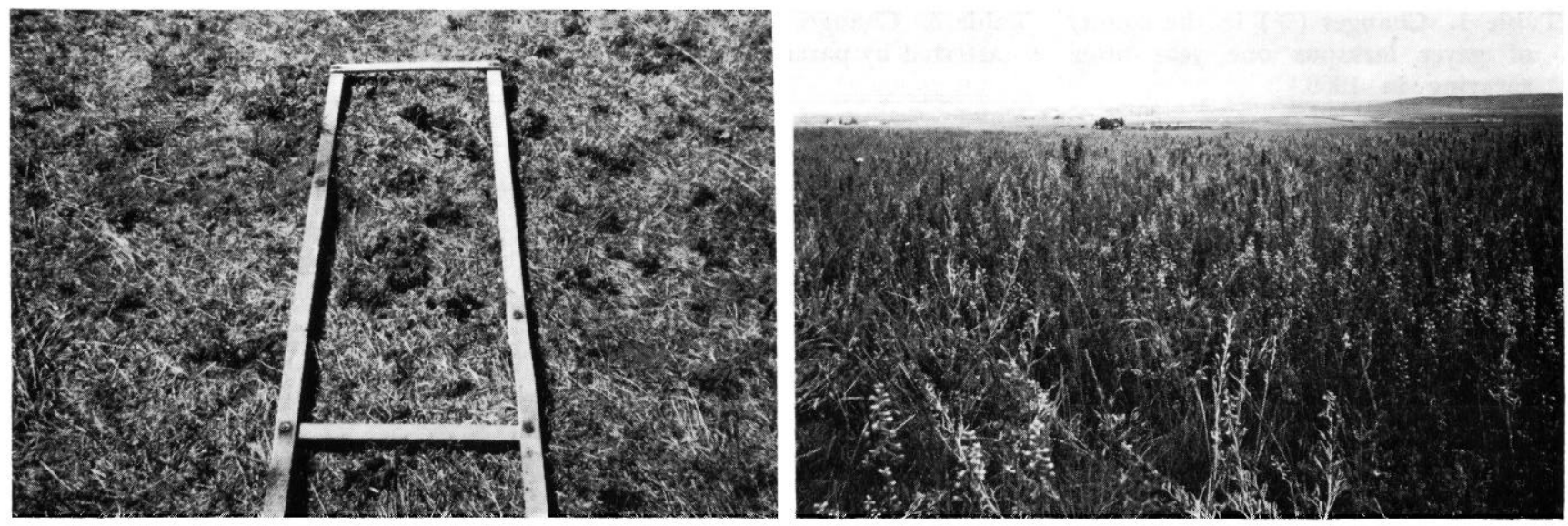

FIG. 1. Geyer larkspur begins growth in April (left) and flowers in July (right). It is poisonous to cattle throughout the growing season.

whether the lethal effects of paraquat should be attributed to a natural susceptibility of geyer larkspur to defoliation or to a translocated phytotoxic effect.

\section{Methods}

Paraquat and 2,4-D in 1969

A $2 \times 2 \times 2$ factorial experiment, in 3 randomized blocks, included 2 dates of spraying (April 28 and May 12, 1969), 2 rates of 2,4-D (none and $2 \mathrm{lb}$./acre), and 2 rates of paraquat (none and $1 / 4$ lb./acre), which was applied 2 days after the 2,4-D. However, since the $1 / 4 \mathrm{lb}$./acre rate of paraquat applied April 30 incompletely desiccated geyer larkspur, the rate was increased to $1 / 2 \mathrm{lb}$./acre on May 14.

\section{Experiments in 1970}

Rate of paraquat.-Paraquat at none, $1 / 4,1 / 2$, and $3 / 41 b$./acre was applied on May 6, 1970. The experiment included 6 replications in a completely random design.

Date of paraquat.-Paraquat was applied at 1/2 lb./acre on May 6, May 18, May 25, and June 2, 1970. The experiment included 6 replications in a completely random design.

Mechanical defoliation.-All herbage was clipped to ground level by hand on May 8, May 15 , May 22, May 29, or June 5, 1970. The experiment included 4 replications in a completely random de- sign. Individual plots, located to include high larkspur densities, were 14 inches wide by 10 feet long. Geyer larkspur plants were counted on May 8, 1970, and May 1, 1971.

\section{Treatment and Sampling Methods}

Paraquat and 2,4-D were diluted in water containing $0.1 \%(\mathrm{v} / \mathrm{v})$ of alkyarylpolyoxyethylene glycol and applied broadcast with a boomtype plot sprayer at a total spray volume of 20 gpa. Individual plots prepared for spraying experiments were 12 by 45 feet.

Treatment effects on geyer larkspur were evaluated by counting the number of plants on 100 square feet of each plot in May the year of spraying and in May one year later, in some cases also two years later. Treatment effects on other species were evaluated by frequency of occurrence involving 50 placements of a 16 by 16-inch quadrat on each plot one year after treatment. Frequency percentages were transformed to apparent density by the equation $\mathrm{d}=-\log _{\mathrm{e}}(\mathrm{q} / 100)$, where $d$ is apparent density and $q$ is the complement of frequency percentage, to estimate mortality percentages (Hyder, 1971).

Herbage samples were cut with a rotary lawnmower leaving $1^{1 / 2}$ inches or about $300 \mathrm{lb}$./acre of uncut stubble in 1970, and with a rotary mower of our design leaving about $1 / 4$ inch or about $50 \mathrm{lb}$./acre of stubble in 1971. Since yields between years are not compared to determine treatment effects, the amounts of uncut stubble are not added to yield values. Herbage samples were oven dried at $70 \mathrm{C}$.

All plots were located on mixedgrass prairie about 5 miles south of Cheyenne, Wyoming.

\section{Results}

Susceptibility of Geyer Larkspur to Paraquat

Paraquat and 2,4-D in 1969.Desiccating geyer larkspur with paraquat after spraying with 2,4-D failed to increase the effect of 2,4-D (Table 1). However, paraquat alone, at either $1 / 4$ or $1 / 2 \mathrm{lb}$./acre, was more effective than 2,4-D at $2 \mathrm{lb}$./acre. Paraquat at 1/2 lb./acre applied May 14, when the flowering stems were slightly above ground, killed $90 \%$ of the plants. On the same plots 2 years after spraying (in 1971), the reduction in geyer larkspur amounted to $77 \%$, but all treatments, including unsprayed check, allowed a little increase in number of geyer larkspur in 1971. Paraquat at $1 / 2$ 1b./acre desiccated all species within 1 week. Geyer larkspur and most annual species failed to grow back after treatment, but essentially all other perennial species grew back quickly.

Since paraquat alone applied in 1969 killed geyer larkspur, additional trials were planned to verify and expand the results. Subsequent 
Table 1. Changes (\%) in the counts of geyer larkspur one year after spraying in 1969.1

\begin{tabular}{|c|c|c|c|}
\hline \multirow{2}{*}{$\begin{array}{l}\text { Date of } \\
\text { treatment }\end{array}$} & \multirow{2}{*}{$\begin{array}{l}\text { Rate of } \\
\text { paraquat } \\
\text { (lb./acre) }\end{array}$} & \multicolumn{2}{|c|}{ Rate of $2,4-\mathrm{D}$} \\
\hline & & 0 & 2 lb./acre \\
\hline \multirow{2}{*}{ April $28^{2}$} & 0 & $-4 a$ & $-42 b c$ \\
\hline & $1 / 4$ & $-57 \mathrm{~cd}$ & $-62 \mathrm{~cd}$ \\
\hline \multirow[t]{2}{*}{ May $12^{2}$} & 0 & $+8 a$ & $-33 b$ \\
\hline & $1 / 2$ & $-90 \mathrm{e}$ & $-75 \mathrm{de}$ \\
\hline
\end{tabular}

${ }^{1}$ Percentage values followed by the same letter are not different at the $95 \%$ level of probability.

${ }^{2}$ Sprays containing 2,4-D were applied on the dates given, and paraquat was applied 2 days later.

experiments included various rates and times of treatment with paraquat to determine best treatments. Mechanical defoliation, also, was included to determine whether the lethal effects of paraquat should be attributed to a natural susceptibility of geyer larkspur to defoliation or to some translocated phytotoxic effects.

Date of paraquat.--Paraquat applied at $1 / 2$ lb./acre on May 6, May

Table 2. Changes (\%) in apparent densities of species that were significantly affected by paraquat applied in 1969.1

\begin{tabular}{lcc}
\hline \hline & \multicolumn{2}{c}{$\begin{array}{c}\text { Rate of paraquat } \\
\text { (lb./acre) }\end{array}$} \\
\cline { 2 - 3 } \multicolumn{1}{c}{ species } & $1 / 4$ & $1 / 2$ \\
\hline Slimleaf goosefoot & $+111^{*}$ & $+219^{*}$ \\
Greenflower & & \\
$\quad$ pcpperwccd & +46 & $+185^{*}$ \\
Geyer larkspur2 & $-57^{*}$ & $-90^{*}$ \\
Textile onion & $-81^{*}$ & $-100^{*}$ \\
White biscuitroot & $-52^{*}$ & $-59^{*}$ \\
\hline
\end{tabular}

1 Changes are based on differences between treated and untreated plots. All plots were sampled for the frequency of occurrence of species in 16 by 16 -inch quadrats in May 1970. Frequency percentages were transformed to apparent densities for analysis of variance and the calculation of percentage changes due to treatment.

${ }^{2}$ Changes for geyer larkspur were determined by counting the plants on 100 square feet per plot before and one year after spraying.

* Changes in apparent density were significant at the $95 \%$ level of probability.

Table 3. Changes $(\%)$ in apparent densities of species that were significantly affected by paraquat applied at $1 / 2 \mathrm{lb}$./acre on four dates in 1970.1

\begin{tabular}{lcccc}
\hline \hline \multirow{2}{*}{\multicolumn{1}{c}{ Species }} & \multicolumn{4}{c}{ Treatment date } \\
\cline { 2 - 5 } Scarlet globemallow & May 6 & May 18 & May 25 & June 2 \\
Needleandthread & -8 & $+159^{*}$ & +69 & +68 \\
Sandberg bluegrass & +36 & +77 & +31 & $+169^{*}$ \\
Textile onion & $-79^{*}$ & $-68^{*}$ & $-96^{*}$ & $-62^{*}$ \\
White biscuitroot & $-90^{*}$ & $-85^{*}$ & $-90^{*}$ & $-85^{*}$ \\
Geyer larkspur (by frequency) & $-83^{*}$ & $-94^{*}$ & $-82^{*}$ & $-72^{*}$ \\
Geyer larkspur (by counting) & $-89^{*}$ & $-95^{*}$ & $-89^{*}$ & $-71^{*}$ \\
\hline
\end{tabular}

1 Changes are based on differences between treated and untreated plots. All plots were sampled for the frequency of occurrence of species in 16 by 16-inch quadrats in May 1971. Frequency percentages were transformed to apparent densities for analysis of variance and the calculation of percentage changes due to treatment.

* Values are significantly different from zero $(95 \%$ level of probability).

18, May 25, and June 2, 1970, killed $89,95,89$, and $71 \%$ of geyer larkspur plants, respectively. The smallest significant range $(95 \%$ level of probability) for comparing two consecutive means is $6 \%$. Thus, the greatest mortality (95\%) was obtained in mid-May when the flowering stems of geyer larkspur were slightly above ground. Spraying at an earlier time allowed regrowth of some of the large plants, while spraying on or after May 18 prevented regrowth of geyer larkspur. Paraquat effectiveness dropped off rapidly after May 25.

Root systems excavated at different times after treatment exhibited a darkening of root tissue, which appeared first in dormant buds, in 3 to 4 weeks. This observation suggested that paraquat produced a translocated phytotoxic effect on geyer larkspur.

Rate of paraquat.- The changes in geyer larkspur counts amounted to $-3,-75,-89$, and $-89 \%$ for paraquat rates of $0,1 / 4,1 / 2$, and $3 / 4$ lb./acre. The smallest significant range for comparing two consecutive means is $7 \%$ for the $95 \%$ level of probability. Thus, rates of $1 / 2$ and $3 / 4 \mathrm{lb}$./acre were more effective than $1 / 4$ lb./acre.

Clipping experiment.-Clipping after mid-May, when the flower stems of large plants were above ground, prevented regrowth and flowering the year of treatment. However, in 1971 there was no significant reduction in either the number of plants or plant vigor by any time of previous clipping. Since mechanical defoliation failed to kill plants, paraquat must have produced a translocated phytotoxic effect on this species.

\section{Susceptibilities of Other Species}

Two perennial species, in addition to geyer larkspur, decreased significantly the year after treatment with paraquat in 1969 (Table 2). Textile onion (Allium textile Nels. \& Macbr.) was essentially eliminated by $1 / 2 \mathrm{lb}$./acre of paraquat, and white biscuitroot ( $C y$ mopterus acaulis (Pursh) Raf.) was moderately susceptible. On the other hand, slimleaf goosefoot (Chenopodium leptophyllum Nutt.) and greenflower pepperweed (Lepidium densiflorum Schrad.), both annual forbs, increased significantly (95\% probability) one year after treatment with paraquat.

Five perennial species in addition to geyer larkspur changed significantly after being treated with paraquat in 1970 (Table 3). As in 1969, textile onion and white biscuitroot decreased significantly. Sandberg bluegrass (Poa secunda Prcsl.), which appcared resistant in 1969, was susceptible in 1970. Both 
scarlet globemallow (Sphaeralcea coccinea (Pursh) Rydb.) and needleandthread (Stipa comata Trin. and Rupr.) increased significantly after one date of spraying. Table 3 includes percentage changes of geyer larkspur as determined by frequency sampling and by counting plants. The two methods of evaluating changes in geyer larkspur gave nearly identical results.

Since very few perennial species were susceptible to paraquat, a list of those documented as resistant is given in Table 4. Other perennial species were too rare to indicate resistance or susceptibility to paraquat.

\section{Herbage Yields}

Treatment of mixed-grass prairie with 2,4-D generally increased herbage yields the year after treatment (Hyder, 1971). Paraquat, however, should decrease yields at least in the year of treatment. Thus, yields were taken July 20, 1970, after paraquat treatments on May 6, May 18, May 25, and June 2, 1970. Yields amounted to 362 , 380,311 , and $296 \mathrm{lb}$./acre, respectively by dates of treatment; whereas, the yield on untreated plots averaged $364 \mathrm{lb}$./acre. Although these differences were not significant at $95 \%$, treatments in late May and early June apparently decreased the yield about $15 \%$ not counting the uncut stubble. Regrowth herbage remained green later in the season and was greatly preferred by cattle in August.

In the ycar after treatment with paraquat in 1969 and 1970, herbage yields were the same as on untreated plots.

\section{Discussion}

Both geyer larkspur and textile onion were highly susceptible to paraquat. White biscuitroot was moderately susceptible. Most grasses and sedges appeared to tiller less profusely after treatment, even when their frequency of occurrence remained unchanged. Sandberg bluegrass was most suscepti-

Table 4. Important perennial species documented as resistant to paraquat applied in 1969 and 1970.

Species name

Year observed

Sandberg bluegrass (Poa secunda Presl)

1969 a

Needleandthread (Stipa comata Trin. and Rupr.)

1969

Scarlet globemallow (Sphaeralcea coccinea (Pursh) Rydb.)

1969

Bladderpod (Lesquerella macrocarpa A. Nels.)

1969

Plains pricklypear (Opuntia polyacantha Haw.)

1969

1969

Western wheatgrass (Agropyron smithii Rydb.)

1969 \& 1970

Blue grama (Bouteloua gracilis (H.B.K.) Lag.)

$1969 \& 1970$

Sun sedge (Carex heliophila Mackenz.)

Junegrass (Koeleria cristata (L.) Pers.)

Fringed sagebrush (Artemisia frigida Willd.)

Bluebells (Mertensia lanceolata (Pursh) A. DC.)

1969 \& 1970

$1969 \& 1970$

$1969 \& 1970$

$1969 \& 1970$

Woody buckwheat (Eriogonum effusum Nutt.)

$1969 \& 1970$

Common starlily (Leucocrinum montanum Nutt.)

$1969 \& 1970$

Drummond milkvetch (Astragalus drummondii Dougl.)

$1969 \& 1970$

Scarlet gaura (Gaura coccinea Nutt. ex Pursh)

1969 \& 1970

Showy peavine (Lathyrus polymorphus Nutt.)

1970

Eveningprimrose (Oenothera coronopifolia (Torr. \& Gray)

b $\quad 1970$

"See text for changes in 1970.

b Frequency was too small to justify evaluation.

ble, but all grasses and sedges probably were damaged temporarily, as shown by small reduction in herbage yield the year of treatment. Some, but not all, of the apparent decrease in sandberg bluegrass and increase in needleandthread could have been due to incorrect identification of these species at the early stage of vegetative development.

Paraquat at $1 / 2$ lb./acre desiccated all species, most of which began regrowth in 2 weeks after treatment. If the paraquat was applied after the flower stems of geyer larkspur were above ground, there was no regrowth by the larkspur. Consequently, an area would be safe for cattle grazing in about 3 weeks after treatment with paraquat, as far as geyer larkspur is concerned. That would be about 6 wceks earlier than natural maturing and drying of geyer larkspur.

A $90-95 \%$ reduction in number of geyer larkspur plants the year after treatment is considered excellent kill. However, even this degree of control may not be enough to prevent cattle poisoning. Geyer larkspur densities run over 4 plants per square foot in some places. Thus, a 95\% mortality could leave a density of 1 plant per 5 square feet. Thick stands might need to be retreated. Furthermorc, ncw plants arising from seed could gradually increase the hazard. In any event, repeated treatments may be necessary.

\section{Literature Cited}

Calderbank, A. 1968. The bipyridylium herbicides. Adv. in Pest Control 8:127-235. John Wiley \& Sons, Inc., New York.

Evans, R. A., R. E. Eckert, JR., and B. L. KAY. 1967. Wheatgrass establishment with paraquat and tillage on downy brome ranges. Weeds 15:50-55.

Hyder, D. N. 1971. Species susceptibilities to 2,4-D on mixed-grass prairie. Weed Sci. 19:526-528.

Hyder, D. N., and L. D. Sabatka. 1972. Geyer larkspur phenology and response to 2,4-D. Weed Sci. 20:31-33.

KAY, B. L. 1964. Paraquat for selective control of range weeds. Weeds 12:192-194. 
KAY, B. L. 1968. Effects of paraquat on yield and composition of a subclover-hardinggrass pasture. Weed Sci. 16:66-68.

Kay, B. L. 1970. Paraquat curing of seeded dryland pasture species. Wallace, Joe D., F. A. Sneva, R. J. J. Range Manage. 23:407-411. Raleigh, And C. B. Rumburg. 1966. SNeva, F. A. 1967. Chemical curing Digestibility of chemically cured of range grasses with paraquat. J. range forage. Proc. West. Sec. Am. Range Manage. 20:389-394. $\quad$ Soc. Animal Sci. 17:385-390. 